\title{
Improving mortality data in South Africa: review of next of kin statements to determine cause of death in police certification
}

\author{
Leonard B Lerer
}

\begin{abstract}
Study objective-The study aimed to improve mortality data by finding ways of reducing the large number of deaths certified as being from "ill-defined" causes (ICD 780-798) in South Africa. This problem is attributable to the absence of cause of death information in many cases where the police issue the death certificate.

Design and setting-A total of 600 consecutive death certification records at the Salt River State Mortuary, Cape Town were reviewed. Measurements and main results-Altogether $347(58 \%)$ deaths were from unnatural causes, $111(18 \%)$ were certified by a doctor, $83(14 \%)$ were certified as being the result of natural causes after a necropsy, and $59(10 \%)$ were certified by the police as being from natural causes. Analysis of sworn statements obtained from the next of kin of all those certified dead by the police rather than a doctor provided a clear cause of death in $72.9 \%$, and a history of recent contact with health services (less than one week previously) in $47 \cdot 5 \%$. All infants certified dead by the police had a history consistent with diarrhoeal disease.

Conclusions-The method of death certification may be an indicator of access to health care and reviewing sworn statements to determine the cause of death should improve the quality of mortality data in the developing world.
\end{abstract}

f Epidemiol Community Health 1993; 47: 248-250

Mortality statistics are an important indicator of health status ${ }^{1}$ and their critical examination is vital for the development of an accurate information system - the foundation of essential national health research. ${ }^{2}$ A substantial proportion of deaths in South Africa are classified as "ill-defined": this constituted the leading cause of death in the black African population in $1986 .^{3}$ The extent of underregistration and the poor quality of the data for most South Africans caused leading researchers to describe African mortality statistics as "a black hole". ${ }^{4}$ Deaths as a result of uncertain causes are recorded as "ill-defined" (International Classification of Disease (ICD) $780-798)^{5}$ by the Central Statistical Services (the government agency responsible for the production of national mortality statistics ${ }^{3}$ ) with consequent deleterious results. In Port Elizabeth, a study of deaths from ill-defined causes concluded that the root of the problem lay in the high proportion of deaths certified by a police officer instead of a doctor. ${ }^{6}$
A study was undertaken in metropolitan Cape Town to investigate further death certification by the police and to determine the utility of sworn statements obtained from the next of kin in providing information about access to health care and the cause of death.

\section{Methods}

Death certificates are usually issued by a medical practitioner. Where the deceased did not have a regular medical attendant or where it is impossible to issue a certificate stating that death was from natural causes, however, the body is transferred to a state mortuary where a necropsy may be performed. If the necropsy confirms a natural cause of death, an autopsy certificate is issued with a cause of death (where ascertainable) given. An investigating police officer may, however, issue a certificate stating that to the best of his knowledge and belief and based on a sworn statement from a relative of the deceased, the death was solely and exclusively the result of natural causes. In these cases, no necropsy is performed, death certificates contain no information on the medical history or cause of death, and the deaths are classified as being the result of "ill-defined" causes. In South Africa a death must be registered before documentation for burial or cremation can be obtained. Police death certification was introduced to reduce the hardship suffered by the deceased's family, who often had problems in obtaining medical practitioner death certificates, especially in rural areas.

The removal of established coloured communities to the Cape Flats, and the influx of African settlement to informal areas on the periphery of the city since the mid-1980s have been important events in the social history of metropolitan Cape Town. ${ }^{7}$ Inequalities in access to health care are largely based on the system of apartheid, ${ }^{8}$ and although there is now transition to a more equitable social structure, most black South Africans rely on overburdened and financially constrained state funded tertiary level and community based health care facilities.

This study was conducted at the Salt River State Mortuary which processes over $90 \%$ of deaths registered with the police in metropolitan Cape Town. Six hundred consecutive deaths registered from 1 January 1991 were examined. The types of death certified were grouped into:

(1) Deaths from unnatural causes, including murder, transport accident, suicide, and drowning;

(2) Deaths certified by a medical practitioner as being from natural causes;

(3) Deaths certified as being the result of natural causes after a necropsy; 
(4) Deaths certified by the police as being the result of natural causes, based on a sworn statement of a relative, and with no specific cause of death recorded on the certificate.

The age and race distribution of those who had died was examined. The study then focused on the police certified deaths and individual records were examined. Sworn statements obtained from the next of kin were studied to determine whether the deceased had visited a hospital, clinic, or private practitioner within one week of death and if it were possible for someone with a medical training (in this case a medical practitioner) to ascertain a cause of death from the information provided.

The process of reading the sworn statements attempted to approximate to the standard international form of medical certificate of causes of death ${ }^{9}$ by seeking the "disease or condition directly leading to death". A case was regarded as having a clear cause of death when an antecedent history, such as a hospital diagnosis of heart disease or cancer, was accompanied by a history of symptoms and signs consistent with the condition resulting in death. In cases where only one of the aforementioned criteria was satisfied, the cause of death was regarded as unclear. Infant deaths certified by the police were compared with those that had been certified after necropsy.

\section{Results}

Of the 600 deaths examined, $347(58 \%)$ were the result of unnatural causes, $111(18 \%)$ were certified by a medical practitioner, $83(14 \%)$ were certified as being the result of natural causes after necropsy, and $59(10 \%)$ were certified by the police as being due to natural causes. Table I gives the age and sex distribution of these deaths and shows that most violent and accidental deaths were in men. Deaths certified as the result of natural causes after a necropsy mainly occurred in infants and in those aged 25-64 years and the distribution of deaths certified by the police was similar. White South Africans constituted a relatively small proportion of all death categories (table II). This was particularly evident in cases of natural death. Of the 59 deaths certified by the police, just under half $(47 \cdot 5 \%)$ had a history of contact with medical care in the week before death. It was possible to ascertain a cause of death in almost three quarters $(72 \cdot 9 \%)$ of the cases,

Table I Percentage of deaths in age categories and ratio of male to female deaths by death certificate type

Table II Percentage of deaths in relation to race and type of death certificate

\begin{tabular}{lccccccc}
\hline $\begin{array}{l}\text { Type of } \\
\text { death } \\
\text { certificate }\end{array}$ & \multicolumn{1}{l}{ Age $(y)$} & & & & $\begin{array}{l}\text { Malel } \\
\text { female } \\
\text { ratio }\end{array}$ \\
\cline { 2 - 8 } & 1 & $1-4$ & $5-24$ & $25-64$ & $65+$ & & \\
\hline $\begin{array}{l}\text { Unnatural causes } \\
\text { (n=347) }\end{array}$ & 2.3 & 4 & 23 & 63 & 7.7 & 4.16 \\
$\begin{array}{l}\text { Natural causes } \\
\text { after necropsy } \\
\text { (n=83) }\end{array}$ & 38.6 & 1.2 & 6.0 & 45.8 & 8.4 & 1.37 \\
$\begin{array}{l}\text { Certified by } \\
\text { medical }\end{array}$ & 1.8 & 0.9 & 2.7 & 53.2 & 41.4 & 2.36 \\
$\begin{array}{l}\text { practitioner } \\
\text { (n=111) }\end{array}$ & 22 & 3.4 & 1.7 & 47.5 & 25.4 & 2.05 \\
$\begin{array}{l}\text { Certified by } \\
\text { police (n=59) }\end{array}$ & 22 & & & & & &
\end{tabular}

\begin{tabular}{|c|c|c|c|}
\hline Type of death certificate & African & Coloured & White \\
\hline $\begin{array}{l}\text { Unnatural causes }(n=347) \\
\text { Natural causes }\end{array}$ & 37 & $48 \cdot 9$ & $14 \cdot 1$ \\
\hline $\begin{array}{l}\text { necropsy ( } n=83 \text { ) } \\
\text { Certified by medical }\end{array}$ & $44 \cdot 6$ & $45 \cdot 8$ & $9 \cdot 6$ \\
\hline $\begin{array}{l}\text { practitioner }(n=111) \\
\text { Certified by police }(n=59)\end{array}$ & $\begin{array}{l}31 \cdot 5 \\
50 \cdot 8\end{array}$ & $\begin{array}{l}62 \cdot 2 \\
40 \cdot 7\end{array}$ & $\begin{array}{l}6 \cdot 3 \\
8 \cdot 5\end{array}$ \\
\hline
\end{tabular}

based on the sworn statement of next of kin (table III). Table IV gives the causes of death obtained from the sworn statements relating to the 30 adults certified dead by the police. Comparison between necropsy and police certified infant deaths (table V) showed substantial differences in the cause of death between the two groups.

Table III Percentage of police certified deaths in relation to availability of cause of death information and recent medical attention $(n=59)$

\begin{tabular}{lll}
\hline \multirow{2}{*}{$\begin{array}{l}\text { Medical attention less } \\
1 \text { week before death }\end{array}$} & \multicolumn{2}{l}{ Cause of death from statement } \\
\cline { 2 - 3 } & Clear & Unclear \\
\hline Yes & $32 \cdot 2$ & $15 \cdot 3$ \\
No & $40 \cdot 7$ & $11 \cdot 8$ \\
\hline
\end{tabular}

Table IV Ranking of the most frequent adult causes of death in police certified cases $(n=30)$

\begin{tabular}{lr}
\hline Ischaemic heart disease & 15 \\
Pulmonary tuberculosis & 7 \\
Cerebrovascular disease & 3 \\
Gastric carcinoma & 2 \\
Oesophageal carcinoma & 1 \\
Bronchial carcinoma & 1 \\
Haematological malignancy & 1 \\
\hline
\end{tabular}

Table $V$ Percentage of deaths certified by the police or after necropsy in infants in relation to specific cause of death

\begin{tabular}{lll}
\hline Cause of death & $\begin{array}{l}\text { Police certification } \\
(n=13)\end{array}$ & $\begin{array}{l}\text { Necropsy } \\
(n=32)\end{array}$ \\
\hline $\begin{array}{l}\text { Diarrhoeal disease } \\
\text { Sudden infant }\end{array}$ & 100 & $31 \cdot 3$ \\
death syndrome & - & $37 \cdot 4$ \\
Bronchopneumonia & - & 12.5 \\
Other & - & $18 \cdot 8$ \\
\hline
\end{tabular}

\section{Discussion}

The number of unnatural deaths found during the study periods reflects a pattern of mortality that constitutes a major health problem in South African men. ${ }^{1011}$ The high rate of police death certification and necropsy may reflect difficulties in obtaining death certificates from medical practitioners. The areas from which these subjects came are generally poorly served by private medical practitioners and most of the public health facilities are not open at night or over weekends. ${ }^{12}$ It is also likely that the poor are forced to use police facilities to remove, transport, and store bodies, with consequent higher police certification and necropsy rates.

Occasionally, the statement of the next of kin would recount an attempt to obtain a death certificate from a hospital or clinic where the deceased had been treated. These attempts failed, either because of difficulties in obtaining the medical record or inability to find the medical practitioner who had treated the deceased and a general reluctance on the part of health care professionals to be involved in the issuing of death certificates. Contact with the health services within one week of death does not indicate that all these cases had problems in obtaining medical death certificates. It is possible that families did not realise that death certificates could be obtained from those involved in the recent medical care of the deceased, and were further constrained by the lack of transport and the prospect of long delays in obtaining the required documentation. Undertaking services are limited in 
areas of informal settlement and this situation has been further exacerbated by conflicts between rival funeral organisations. It must be noted that many health care workers, burdened with high patient volumes, would obviously accord the provision of a death certificate low priority.

All those involved in health care must be trained in the importance of providing death certificates in order to minimalise hardship suffered by bereaved families. Also important is the upgrading of medical practitioner death certification, with emphasis on providing accurate medical cause of death information. ${ }^{13}$ The importance of mortality statistics as a basis for health resource allocation decisions must be recognised more widely. ${ }^{1}$

This study illustrates that next of kin statements can provide valuable information on the cause of death where this is ill-defined. Conventional post mortem interviews rely on either open ended questions or structured questionnaires administered by trained medical or lay personnel. Recent studies have shown that post mortem interviews provide a high level of sensitivity and specificity in the diagnosis of fatal illnesses and are an important method of obtaining mortality information in the developing world. ${ }^{14} 15$

The system of police death certification is based on obtaining a sworn statement from the next of kin as to the circumstances surrounding the illness and final days of the deceased. This constitutes a narrative account with a minimum of additional questioning. The aim of this statement is not to ascertain a specific medical cause of death, but rather to exclude any unnatural cause of death that would require further investigation. In Cape Town, this statement is usually obtained by a police detective with no additional nosological training. This enables the investigating police officer to issue a death certificate. As this certificate contains no cause of death information, however, these deaths are recorded as "ill-defined". The exclusion of specific cause of death information from the certificate is based on the fact that when untrained police provided the cause of death, problems were encountered with inaccurate, and occasionally, bizarre information. ${ }^{6}$

The statements obtained by the investigating police officer were clear enough to allow a medical practitioner to ascertain a cause of death in almost three quarters of the cases. In most accounts, both the background circumstances and the immediate events surrounding the death concurred in providing a clear cause of death. The variety of accounts and causes of death make it unlikely that the police officer did indeed influence the narrative obtained. Most of the interviews were conducted in Afrikaans which is not the home language of the African next of kin and further research into the effect of language on the sensitivity of these statements is required. The "language of interview" may in itself be a good indicator of health status. ${ }^{16}$

The lack of association between contact with health care and next of kin knowledge of the cause of death may be a result of the fact that patients with clearly terminal conditions may not have visited hospitals or clinics regularly because of lack of mobility and financial constraints. A number of cases required police certification although the deceased had, according to the next of kin, been discharged recently from hospital "in order to die at home".

A major concern is the deleterious effect of high levels of "ill-defined" infant deaths on national diarrhoeal disease mortality statistics. ${ }^{17}$ The predominance of diarrhoeal disease deaths in this study is attributable to the fact that it was conducted in the summer, and an active programme of infant mortality surveillance shows that acute respiratory infection ${ }^{18}$ is an important cause of infant mortality in South Africa. One specific virtue of examining relatives' statements may be that it allows some understanding of the attitude and beliefs surrounding the event described. This could be of importance in understanding the sociocultural complexities of infant mortality. ${ }^{19}$

The application of innovative nosological techniques such as the analysis of sworn statements associated with sentinel health events ${ }^{20}$ could be used in conjunction with direct ${ }^{21}$ and indirect ${ }^{22} 23$ methods to improve the quality of mortality data in the developing world.

1 Ruzicka LT, Lopez AD. The use of cause-of-death statistics for health situation assessment: national and internationa experiences. Wld Hlth Statist Quart 1990; 43: 249-57.

2 Evans JR. Essential national health research-a key to equity in development. New Engl F Med 1990; 323: 913-5.

3 Kielkowski D, Steinberg M, Barron PM. Life after deathmortality statistics and the public health. S Afr Med $\mathcal{F} 1989$ 76: 672-5.

4 Botha JL, Bradshaw D. African vital statistics-a black hole? $S$ Afr Med f 1985; 67: 977-81.

5 World Health Organisation. Manual of the international classification of diseases, injuries and causes of death 9 th Revision Geneva: WHO, 1978

6 van der Merwe S, Yach D, Metcalf CA. Peering into the black hole- the quality of black mortality data in Port Elizabeth and the rest of South Africa. S Afr Med F 1991; 79: 419-22.

7 Dewar D, Watson V. An overview of development problems in the Cape Town metropolitan area. Cape Town: University of the Cape Town, 1990. UPRU working paper no 40.

8 Botha JL, Bradshaw D, Gonin R, Yach D. The distribution of Botha JL, Bradshaw D, Gonin R, Yach D. The distribution of
health needs and services in South Africa. Soc Sci Med 1988; 26: 845-51.

9 World Health Organisation. Medical certification of cause of death. Instructions for physicians on use of international form of medical certificate of cause of death. Geneva: WHO; 1979.

10 Bradshaw D, Botha D, Joubert G, Pretorius JP, van Wyk R, Yach D. Review of South African mortality. Parow: South African Medical Research Council, 1987.

11 Flisher AJ, Joubert G, Yach D. Mortality from external causes in South African adolescents, 1984-1986. S Afr Med f 1992 81: $77-80$.

12 Community Health Research Project. Access to health services in the greater Cape Town area. Cape Town University of Cape Town, 1983. SALDRU working paper no 55.

13 Lindahl BIB, Glattre E, Lahti R, Magnusson G, Mosbech J. The WHO principles for registering causes of death 467-74.

14 Kalter HD, Gray RH, Black RE, Gultiano SA. Validation of post mortem interviews to ascertain selected causes of death in children. Int f Epidemiol 1990; 19: 380-6.

15 Pacqué-Margolis S, Pacqué M, Dukuly Z, Boateng J, Taylor HR. Application of the verbal autopsy during a clinical trial. HR. Application of the verbal auto
Soc Sci Med 1990; 31: 585-91.

16 Kirkman-Liff B, Mondragón D. Language of interview: relevance for research of southwest Hispanics. Am $\mathcal{f}$ Public relevance for research of so

17 Yach D, Strebel PM, Joubert G. The impact of diarrhoeal Yach D, Strebel PM, Joubert G. The impact of diarrhoeal disease on childhood death

18 von Schimding YER, Yach D, Klein M. Acute respiratory infections as an important causes of childhood deaths in infections as an important causes of childh
South Africa. S Afr Med $\mathcal{7} 1991 ; 80: 79-82$.

19 Scheper-Hughes N. Social indifference to child death. Lancet 1991; 337: 1144-7.

20 Carr W, Szapiro N, Heisler T, Krasner MI. Sentinel health events as indicators of unmet needs. Soc Sci Med 1989; 29 705-14.

21 Koumans EHA. Infant and child mortality in the Elim district, northern Transvaal, 1976-1986, and a comparison of trends $S$ Afr Med Ұ 1992; 81: 202-5.

22 Brass W, Macrae S. Childhood mortality estimated from reports on previous births given by mothers at the time of maternity: I. Preceding births technique. Asian and Pacific Census Forum 1984; 11: 1 .

23 David P, Kawar S, Graham W. Estimating maternal mortality in Djibouti: an application of the sisterhood methods. Int Epidemiol 1991; 20: 551-7. 